\title{
Bioethanol production from oilseed rape straw hydrolysate by free and immobilised cells of Saccharomyces cerevisiae
}

\author{
A. K. Mathew, K. Chaney, M. Crook \& A. C. Humphries \\ Harper Adams University College, Newport, Shropshire, UK
}

\begin{abstract}
Oilseed rape (OSR) straw can serve as a low-cost feedstock for bioethanol production. Glucose and other fermentable sugars were extracted from OSR straw using sulfuric acid pre-treatment and enzymatic hydrolysis. Batch fermentation of enzymatic hydrolysate with Saccharomyces cerevisiae immobilised in Lentikat ${ }^{\circledR}$ was found to be superior to free cells in terms of bioethanol yield. The maximum bioethanol concentration from free and immobilised cells was 6.73 and 9.45 g. $1^{-1}$, respectively, with corresponding yields of 0.41 and $0.49 \mathrm{~g}$ bioethanol. $\mathrm{g}$ glucose $\mathrm{e}^{-1}$.
\end{abstract}

Keywords: bioethanol, dilute acid pre-treatment, immobilisation, oilseed rape straw.

\section{Introduction}

In 2007, consumption of liquid fuels in the transportation sector was 46 million barrels per day and is expected to increase by 67 million barrels per day by 2035 EIA [1]. In 2007, the use of liquid fuels was responsible for $38 \%$ of global greenhouse gas (GHG) emissions, providing a significant contribution to climate change EIA [1]. The replacement of gasoline (petrol) with bioethanol is encouraged globally as a mechanism to reduce exposure to volatility in the oil market, and minimise the extent to which road transport contributes to global warming. Bioethanol can be produced from two different types of feedstocks: first-generation feedstocks (maize, wheat and sugarcane) and second-generation feedstocks (lignocellulosic materials such as straws, forest residue or any agriculture waste) (Balat [2]). Commercial production of bioethanol from firstgeneration feedstocks is limited by land availability, and concerns regarding the 
use of land for fuel as opposed to food production. Second-generation bioethanol production from lignocellulosic material is a complex process compared to firstgeneration feedstocks due to the presence of lignin and hemicellulose. Additional processing steps, referred to as pre-treatment and hydrolysis are essential for extracting sugar from lignocellulosic materials. The pre-treatment process is highly energy intensive and expensive (due to enzyme application during hydrolysis), which means the production of second-generation bioethanol is currently non-competitive to first-generation bioethanol (Lora et al. [3]). Consequently bioethanol produced from second-generation feedstocks is the focus of considerable research and development.

Global cultivation of OSR was 31 million ha in 2009. Assuming a straw yield of 1.5 - 3.0 tonnes per ha (Newman [4]), the amount of OSR straw produced in 2009 was between 46.5 and 93.0 million tonnes. Assuming a bioethanol yield of 2701 tonne $^{-1}$ (Larson [5]) of straw (using existing technology) it is predicted that between 12.5 and 25.0 billion liters of bioethanol could have been produced from OSR straw. Currently OSR straw does not have an existing market and is normally ploughed back into field. Hence bioethanol production from OSR straw could add value to existing crops.

Dilute acid pre-treatment is one of the most commonly used pre-treatment techniques for altering the structure of lignocellulosic materials (Moiser et al. [6]). It mainly breaks the structure of hemicellulose and a small portion of lignin. Dilute acid pre-treatment also leads to the formation of fermentation inhibitors such as acetic acid, hydroxymethylfurfural (HMF) and furfural as a result of sugar degradation (Palmqvist and Hahn-Hagerdal [7]). Dilute acid pre-treatment has been widely studied for a range of feedstocks. Jeong et al. [8] optimised the dilute acid pre-treatment of OSR straw based on the extent to which hemicellulosic sugars (mainly xylose, mannose and galactose) were extracted. Under optimum pre-treatment conditions $\left(1.76 \% \mathrm{H}_{2} \mathrm{SO}_{4}, 152.6^{\circ} \mathrm{C}\right.$ for $\left.21 \mathrm{~min}\right)$ $85.5 \%$ of total sugars were recovered from OSR straw. The inhibitors present in the pre-treated hydrolysate were acetic acid $\left(2.94 \mathrm{~g} \mathrm{l}^{-1}\right)$, 5-hydroxymethylfurfural $\left(0.04 \mathrm{~g} \mathrm{l}^{-1}\right)$ and furfural $\left(0.98 \mathrm{~g} \mathrm{l}^{-1}\right)$. Subsequent enzymatic hydrolysis resulted in a digestibility of $95.4 \%$ after $72 \mathrm{~h}$, compared to a digestibility of $27.1 \%$ for untreated OSR straw. Castro et al. [9] optimised the dilute acid pre-treatment of OSR straw using pre-treatment temperatures between 140 and $200^{\circ} \mathrm{C}$, pretreatment times between 0 and $20 \mathrm{~min}$ and sulfuric acid concentrations between 0.5 and $2.0 \%(\mathrm{w} / \mathrm{w})$. A mathematical model was used to predict the pre-treatment conditions that would result in a cellulose conversion efficiency of approximately $100 \%$. The optimum conditions were predicted to be the application of temperature at $200^{\circ} \mathrm{C}$ for $27 \mathrm{~min}$ at an acid concentration of $0.40 \%$. Mathew et al. [10] studied the dilute acid pre-treatment of OSR straw based on the concentration of glucose recovered after enzymatic hydrolysis. Under optimum pre-treatment conditions $(5 \%(\mathrm{w} / \mathrm{w})$ biomass loading, 2.5\% $(\mathrm{w} / \mathrm{w})$ acid concentration and 90 min pre-treatment time) $81 \%$ of glucan was converted into glucose after $72 \mathrm{~h}$ of enzymatic hydrolysis.

The production of bioethanol using immobilised cells has been well studied. However, previous research has focused on the use of either sugar cane or starch 
hydrolysate as substrate. The advantages of cell immobilisation over free cell fermentation for bioethanol production include a higher volumetric productivity due to higher cell density, enhanced yield and cell viability for repeated cycles of fermentation (Swain et al. [11]). The research presented compares the bioethanol yield and volumetric productivity obtained from the batch fermentation of OSR straw hydrolysate using free and immobilised cells of $S$. cerevisiae.

\section{Materials and methods}

\subsection{Microorganism and media}

S. cerevisiae Type I was grown at $30^{\circ} \mathrm{C}$ and maintained on agar slants at $4^{\circ} \mathrm{C}$ as described by Liu et al. [12]. S. cerevisiae was cultivated in $150 \mathrm{ml}$ conical flasks with $50 \mathrm{ml}$ growth medium (Glucose, 5.0; yeast extract, 0.5; peptone, 0.5; $\mathrm{K}_{2} \mathrm{HPO}_{4}, 0.1 ; \mathrm{MgSO}_{4} .7 \mathrm{H}_{2} \mathrm{O}, 0.1$; expressed in $\mathrm{g} 100 \mathrm{ml}^{-1}$ ) and incubated at $30^{\circ} \mathrm{C}$ in a shaking incubator at $150 \mathrm{rpm}$. After overnight incubation $\left(10^{8}\right.$ cells ml $\left.\mathrm{m}^{-1}\right)$ cells were harvested by centrifugation at $4000 \mathrm{rpm}$ for $15 \mathrm{~min}$ and resuspended in $10 \mathrm{ml}$ growth medium.

\subsection{Sugar extraction from OSR straw}

OSR straw was pre-treated using the optimum dilute sulfuric acid pre-treatment conditions determined previously (Mathew et al. [10]). Following pre-treatment, the slurry was filtered, washed with purite water and the liquid fraction collected. The solid fraction was used for enzymatic hydrolysis using cellulase from Trichoderma ressei ATCC 26921 (25 FPU g ${ }^{-1}$ biomass) and $\beta$-glucosidase from Aspergillus niger (70 CBU g ${ }^{-1}$ biomass) for $72 \mathrm{~h}$, at $50^{\circ} \mathrm{C}$ and $5 \%$ biomass loading using sodium citrate buffer ( $\mathrm{pH}$ 4.8). The hydrolysate was filtered using No.1 Whatman filter paper and liquid fraction was used for fermentation.

\subsection{Immobilisation of yeast cells}

Lentikat $^{\circledR}$ was obtained from geniaLab (Germany) and prepared for immobilisation according to Bezbradica et al. [13] after melting at $90 \pm 3^{\circ} \mathrm{C}$. S. cerevisiae cells were immobilised into Lentikat $^{\mathbb{R}}$ by mixing $10 \mathrm{ml}$ of S. cerevisiae cell suspension with $40 \mathrm{ml}$ of Lentikat ${ }^{\circledR}$ liquid. The mixture was extruded onto petri dishes through a syringe fitted with a needle $(1.25 \times 40 \mathrm{~mm})$. The petri dishes were left to dry in a laminar flow cabinet under a downwards vertical airstream at room temperature for approximately $2 \mathrm{~h}$. The Lentikat ${ }^{\mathbb{R}}$ discs were stabilised and re-swollen in $100 \mathrm{ml}$ stabilising solution (geniaLab, Germany) for $2 \mathrm{~h}$. Lentikat ${ }^{\mathbb{B}}$ immobilised $S$. cerevisiae were allowed to proliferate through overnight incubation in $100 \mathrm{ml}$ growth medium according to Liu et al. [12]. Lentikat ${ }^{\mathbb{B}}$ was selected as an immobilisation support because of its mechanical strength. 


\subsection{Fermentation conditions}

\subsubsection{Bioethanol production from enzymatic hydrolysate using free and immobilised cells of $S$. cerevisiae}

Batch fermentation was completed using free and Lentikat ${ }^{\circledR}$ immobilised cells of $S$. cerevisiae in $150 \mathrm{ml}$ sterile conical flasks with $50 \mathrm{ml}$ of fermentation medium (enzymatic hydrolysate with glucose concentration of $16-19 \mathrm{~g} \mathrm{l}^{-1}$ ) for $24 \mathrm{~h}$ at 30 $\pm 3^{\circ} \mathrm{C}$ and $150 \mathrm{rpm}$. The fermentation medium was composed of glucose, yeast

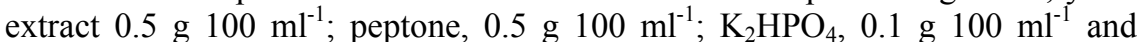

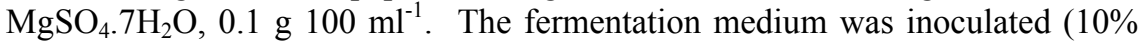
$\mathrm{w} / \mathrm{v})$ either with immobilised or free cells. Samples $(1 \mathrm{ml})$ were withdrawn from the fermentation medium after 2, 4, 6, 10 and 24h, and analysed to determine the glucose and bioethanol concentration. Batch fermentations were completed in triplicate.

\subsubsection{Bioethanol production by immobilised cells of $S$. cerevisiae using acid pre-treatment and enzymatic hydrolysate as substrate}

Batch fermentation was completed using Lentikat ${ }^{\circledR}$ immobilised cells of $S$. cerevisiae as per the method presented in section 2.4.1, but the fermentation medium was composed of the liquid fraction collected immediately following pre-treatment and the enzymatic hydrolysate. The sugars present in the pretreated hydrolysate were xylose, $7.46 \mathrm{~g} \mathrm{l}^{-1}$; glucose, $1.77 \mathrm{~g} \mathrm{l}^{-1}$; galactose, $1.35 \mathrm{~g} \mathrm{l}^{-1}$; arabinose, $0.85 \mathrm{~g} \mathrm{l}^{-1}$. The glucose concentration of the fermentation medium was adjusted to $23 \mathrm{~g} \mathrm{l}^{-1}$ using pure glucose.

\subsection{Analytical methods}

The concentration of bioethanol and glucose present in the fermentation media was analysed using HPLC fitted with a refractive index detector. HPLC analysis was completed according to NREL [14] laboratory analytical procedure.

\subsection{Statistical analysis}

Statistical analysis was completed using Genstat $13^{\text {th }}$ edition. The effect of immobilisation of $S$. cerevisiae in Lentikat ${ }^{(B)}$ supports and free cells was analysed separately by using one-way analysis of variance (ANOVA).

\section{Results}

\subsection{Bioethanol production from enzymatic hydrolysate using free and immobilised cells of $S$. cerevisiae}

Batch fermentation was completed using glucose extracted from the enzymatic hydrolysis of OSR straw as carbon source. Batch fermentation was completed over a $24 \mathrm{~h}$ time period and employed either free or Lentikat ${ }^{\circledR}$ immobilised cells of $S$. cerevisiae (Figure. 1). The concentration of bioethanol produced after $24 \mathrm{~h}$ of fermentation was approximately $40 \%$ higher $(\mathrm{p}=0.021)$ for immobilised cells 

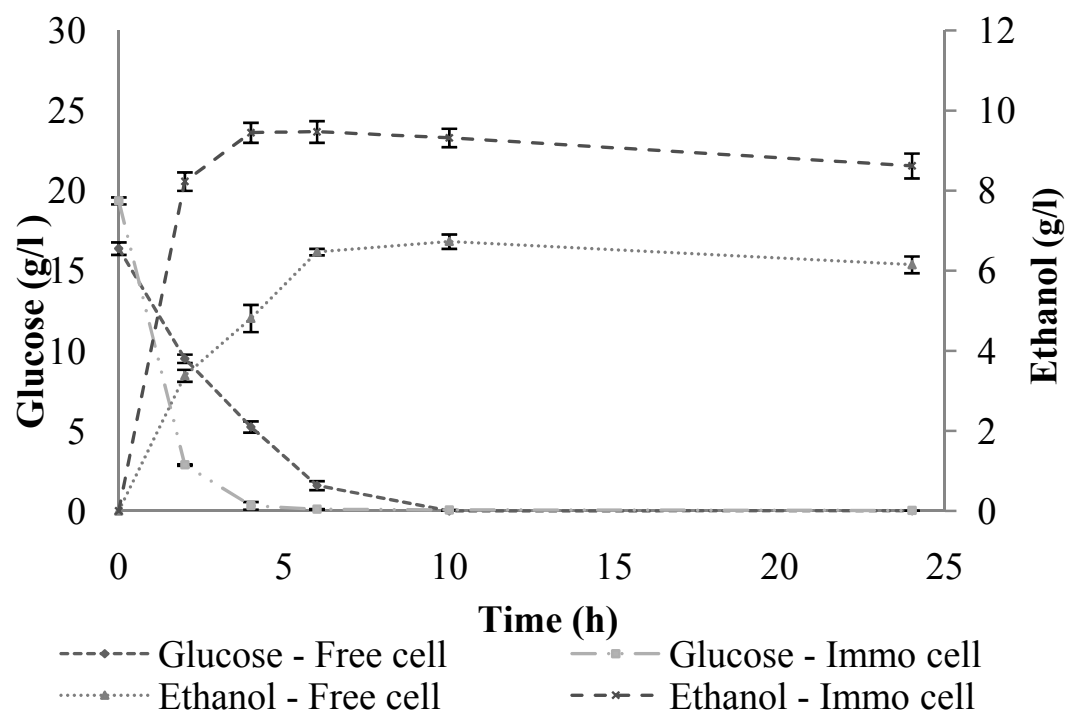

Time (h)

$$
\begin{aligned}
& \text { - }- \text { Glucose - Immo cell } \\
& --\infty-\text { Ethanol - Immo cell }
\end{aligned}
$$

Figure 1: Glucose consumption and ethnaol production using free and immobilsed cells of $S$. cerevisiae.

$\left(8.62 \pm 0.31 \mathrm{~g} \mathrm{l}^{-1}\right)$ compared to free cells $\left(6.15 \pm 0.21 \mathrm{~g} \mathrm{l}^{-1}\right)$. This finding is supported by Swain et al. [11], who demonstrated a $6.7 \%$ increase in bioethanol yield when mahula flowers were fermented with cells immobilised in calcium alginate as opposed to free cells. Glucose was fully consumed within the $24 \mathrm{~h}$ fermentation time period; hence a lower bioethanol yield cannot be attributed to a reduced level of glucose uptake by free cells. The conversion of glucose to bioethanol was significantly faster with immobilised cells than with free cells. A maximum bioethanol concentration of $9.45 \pm 0.25 \mathrm{~g} \mathrm{l}^{-1}$ was achieved within $4 \mathrm{~h}$ of fermentation when immobilised cells were used. This represents a glucose conversion efficiency of approximately $98 \%$ compared to $67 \%$ glucose conversion by free cells in the same time period. The final biomass concentration recorded in Swain et al. [11] was higher in free cell fermentation, suggesting glucose may have been diverted from bioethanol production in order to support cell growth. It took approximately $24 \mathrm{~h}$ for free cells to consume $99 \%$ of the initial glucose present in the medium, demonstrating cell immobilisation resulted in significantly enhanced volumetric productivity. The volumetric productivity of bioethanol fermentation using immobilised S. cerevisiae cells was $4.12 \mathrm{~g} \mathrm{l}^{-1} \mathrm{~h}^{-1}$ compared to $1.69 \mathrm{~g} \mathrm{l}^{-1} \mathrm{~h}^{-1}$ for free cells after $2 \mathrm{~h}$. The volumetric productivity reduced to $0.26 \mathrm{~g} \mathrm{l}^{-1} \mathrm{~h}^{-1}$ and $0.36 \mathrm{~g} \mathrm{l}^{-1} \mathrm{~h}^{-1}$ for free and immobilised $S$. cerevisiae after $24 \mathrm{~h}$ of batch fermentation due to a lower concentration of glucose present in the fermentation medium. At the initial stages of batch fermentation (until $4 \mathrm{~h}$ ), the volumetric productivity of immobilised S. cerevisiae cells was found to be approximately two to three times higher than that of free cells. According to Nedovic and Willaert [25], immobilised cells have less 
hydrodynamic and mechanical stress compared to cells in suspension, which enables the cells to utilise more cellular energy for product formation, resulting an improvement in volumetric productivity.

A decrease in bioethanol concentration was observed with free cells and immobilised cells between 6 and $24 \mathrm{~h}$ of fermentation. However statistical analysis suggested this was not a significant reduction $(p=0.289$ for free cells and $\mathrm{p}=0.224$ for immobilised cells). The same trend was observed in a study conducted by Kuhad et al. [15], where the bioethanol concentration and bioethanol yield reduced between 16 and $24 \mathrm{~h}$ fermentation. The reduction in bioethanol concentration may be due to the oxidation of bioethanol to acetic acid (Christensen et al. [16]) or due to the formation of other by-products such as glycerol and butyric acid (as a result of contamination) (Cheng [17]). Another possible explanation is the consumption of accumulated bioethanol by $S$. cerevisiae that has adapted to simultaneously consume fermentable sugars and bioethanol (Ramon-Portugal et al. [18]). The maximum bioethanol yield obtained from free cells was $0.41 \mathrm{~g}$ bioethanol. $\mathrm{g}$ glucose ${ }^{-1}$ and that of immobilised cells was $0.49 \mathrm{~g}$ bioethanol. $\mathrm{g}_{\text {glucose }}{ }^{-1}$. These yields are less than the stoichiometric bioethanol yield of $0.51 \mathrm{~g}$ bioethanol. $\mathrm{g}$ glucose ${ }^{-1}$. The lower bioethanol yield observed may have been due to the use of glucose for cell growth during fermentation, essentially diverting substrate from bioethanol production.

The maximum theoretical bioethanol conversion (\%) was found to be $80.51 \%$ after $10 \mathrm{~h}$ of fermentation with free cells and $95.66 \%$ after $4 \mathrm{~h}$ of fermentation with immobilised cells. Behera et al. [19] studied the production of bioethanol from mahula flowers using $S$. cerevisiae (strain CTCRI) cells either free in solution or immobilised in agar-agar or calcium alginate. Behera et al. [19] reported theoretical bioethanol conversions of $87 \%, 93 \%$ and $95 \%$ for free cell, cells immobilised in agar-agar and calcium alginate, respectively after $96 \mathrm{~h}$ of fermentation. Bioethanol conversion (\%) with immobilised S. cerevisiae cells in the current study was found to be approximately equal to that of Behera et al. [19]. In contrast to this, Rakin et al. [20] compared bioethanol production from corn meal hydrolysate using S. cerevisiae var. ellipsoideus immobilised into calcium alginate and Lentikat ${ }^{\mathbb{B}}$. S. cerevisiae var. ellipsoideus immobilised in calcium alginate resulted in a higher theoretical bioethanol yield of $111 \%$ compared to $77 \%$ for cell immobilised in Lentikat ${ }^{\circledR}$ discs. In comparison to free cells, immobilised cells were found to result in higher bioethanol concentrations and improved volumetric productivity of batch fermentation by increasing the local population density of cells (Yu et al. [21]; Najafpour et al. [22]).

\subsection{Bioethanol production by immobilised cells of $S$. cerevisiae using acid pre-treatment and enzymatic hydrolysate as substrate}

Batch fermentation was conducted over a $24 \mathrm{~h}$ time period using fermentable sugars extracted from pre-treatment and hydrolysis of OSR straw (i.e. acid pretreatment and enzymatic hydrolysis hydrolysate were combined). The results are shown in figure 2 . The bioethanol concentration obtained after $24 \mathrm{~h}$ of batch fermentation from acid and enzymatic hydrolysate fermentation medium was 
$8.66 \pm 0.09 \mathrm{~g} \mathrm{l}^{-1}$. A maximum bioethanol concentration of $9.26 \pm 0.04 \mathrm{~g} \mathrm{l}^{-1}$ was obtained after $6 \mathrm{~h}$ of fermentation. Similarly to when enzymatic hydrolysate was used as sole substrate, there was a significant reduction $(\mathrm{p}=0.044)$ in bioethanol concentration between 6 and $24 \mathrm{~h}$ of batch fermentation. There was no significant difference observed $(p=0.873)$ in the concentration of bioethanol produced when enzymatic hydrolysate only and acid pre-treatment and enzymatic hydrolysate were used as substrate, even though the initial concentration of fermentable sugars was higher in the latter.

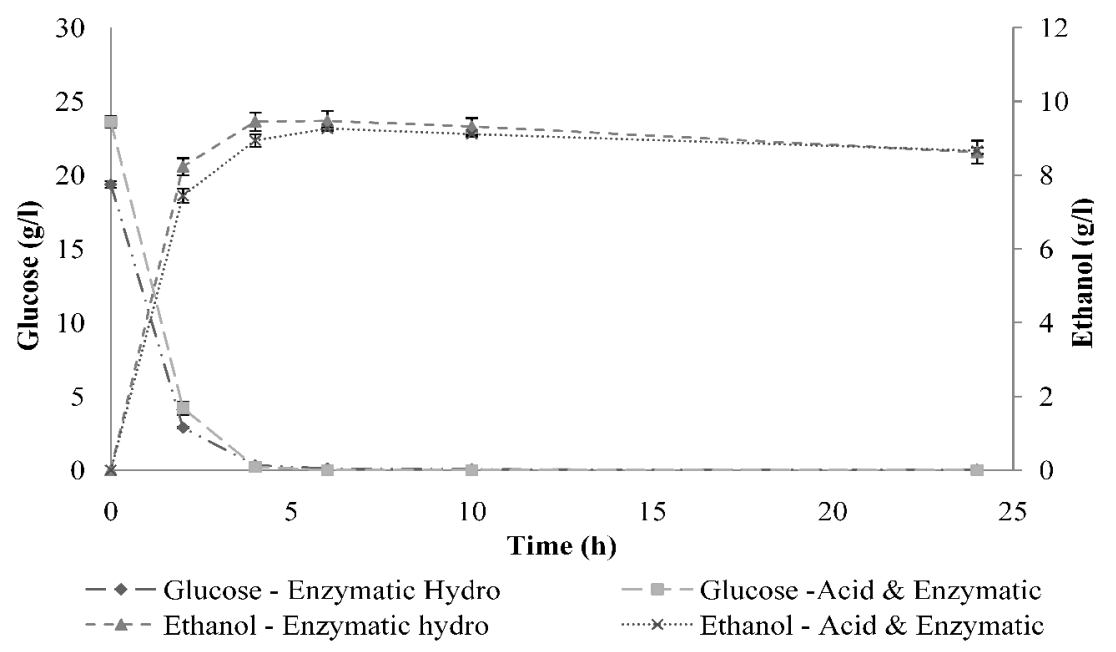

Figure 2: Glucose consumption and bioethanol production from enzymatic hydrolysate, acid and enzymatic hydrolysate using immobilised S. cerevisiae cells.

A bioethanol yield of $0.39 \mathrm{~g}$ bioethanol $\mathrm{g}$ glucose $^{-1}$ was achieved with immobilised cells using acid pre-treatment and enzymatic hydrolysate as substrate. A yield of $0.49 \mathrm{~g}$ bioethanol $\mathrm{g}$ glucose ${ }^{-1}$ was obtained for immobilised cells when enzymatic hydrolysate was used as substrate. The lower bioethanol yield observed when acid and enzymatic hydrolysate was added to the fermentation medium may have been due to the presence of inhibitors such as acetic acid, hydroxymethylfurfural (HMF) and furfural that are produced during acid pre-treatment and which were present in the pre-treatment hydrolysate. These products can inhibit bioethanol production by reducing the activity of several enzymes such as alcohol dehydrogenase, aldehyde dehydrogenase and pyruvate dehydrogenase (Modig et al. [23]).

The volumetric bioethanol productivity of immobilised cells when acid and enzymatic hydrolysate was added to the fermentation medium was $2.24 \mathrm{~g} \mathrm{l}^{-1} \mathrm{~h}^{-}$ after $4 \mathrm{~h}$ of batch fermentation. After $24 \mathrm{~h}$ of fermentation, the volumetric ${ }^{1}$ bioethanol productivity was reduced to $0.36 \mathrm{~g} \mathrm{l}^{-1} \mathrm{~h}^{-1}$. This is similar to the volumetric bioethanol productivity observed after $24 \mathrm{~h}$, for free and immobilised 
cells of S. cerevisiae using enzymatic hydrolysate $\left(0.26\right.$ and $0.36 \mathrm{~g} \mathrm{l}^{-1} \mathrm{~h}^{-1}$, respectively). Behera et al. [19] reported volumetric bioethanol productivities of $0.258,0.262$ and $0.268 \mathrm{~g} \mathrm{l}^{-1} \mathrm{~h}^{-1}$, for cells free in solution, and immobilised in agar-agar and calcium alginate, respectively. The current study demonstrates higher bioethanol productivity in immobilised fermentation compared to Behera et al. [19] whereas the volumetric productivity of free cells was found to be similar to the study conducted by Behera et al. [19]. Petersson et al. [24] demonstrated a bioethanol productivity of $0.91 \mathrm{~g} \mathrm{l}^{-1} \mathrm{~h}^{-1}$ from simultaneous saccharification and fermentation of wet oxidised OSR straw. The ethanol productivity in the current study was found to be lower due to a lower concentration of glucose present in the fermentation medium initially.

From the current study, the maximum theoretical bioethanol yield from acid and enzymatic hydrolysate was approximately $76 \%$, which is less than the maximum theoretical bioethanol yield observed from free cells in suspension using enzymatic hydrolysate as fermentation medium. Hence the current study concluded that fermentation using enzymatic hydrolysate would be better than combined use of pre-treatment and enzymatic hydrolysate for bioethanol production. Potentially the bioethanol yield obtained when pre-treatment hydrolysate is used as carbon source could be increased through the fermentation of pentose sugars.

\section{Conclusion}

Bioethanol production from OSR straw using dilute acid pre-treatment was studied using S. cerevisiae cells free in suspension and immobilised in Lentikat ${ }^{\mathbb{R}}$ discs. Batch fermentation with enzymatic hydrolysate demonstrated the immobilisation of S. cerevisiae cells in Lentikat ${ }^{B}$ discs resulted in improved volumetric productivity and a higher concentration of bioethanol $(9.47 \pm$ $\left.0.27 \mathrm{~g} \mathrm{l}^{-1}\right)$ than when cells free in suspension were used $\left(6.73 \pm 0.18 \mathrm{~g} \mathrm{l}^{-1}\right)$. Batch fermentation of pre-treatment and enzymatic hydrolysate using Lentikat ${ }^{\mathbb{B}}$ immobilised cells did not improve the concentration of bioethanol produced $\left(9.26 \pm 0.04 \mathrm{~g} \mathrm{l}^{-1}\right)$.

\section{References}

[1] United States Energy Information Administration (USEIA). International energy statistics, 1000 Independence Ave., SW, Washington, DC 20585, http://www.eia.gov/

[2] Balat, M., Production of bioethanol from lignocellulosic materials via biochemical pathway: A review. Energy Conversion and Management, 52, pp. 858-875, 2011.

[3] Lora, EES., Palacio, JCE., Rocha, MH., Reno, MLG., Venturini, OJ., Olmo, OA., Issues to consider, existing tools and constraints in biofuels sustainability assessments, Energy, Article in press, 2010.

[4] Newman R. A trial burn of rape straw and whole crops harvested for energy use to assess efficiency implications B/U1/00768/00/00 
http://webarchive.nationalarchives.gov.uk/+/http://www.berr.gov.uk/files/fi le14920.pdf

[5] Larson, D. E. Biofuel production technologies: status, prospects and implications for trade and development, united conference on trade and development UNCTAD/DITC/TED/2007/10, http://www.unctad.org/en/docs/ditcted200710 en.pdf

[6] Mosier, N., Wyman, C., Dale, B., Elander, R., Holtzapple, Y. Y. L. M., Ladisch, M., Features of promising technologies for pre-treatment of lignocellulosic biomass. Bioresource Technology, 96, pp. 673-686, 2005.

[7] Palmqvist, E. \& Hahn-Hagerdal, B., Fermentation of lignocellulosic hydrolysates. II:inhibitors and mechanisms of inhibition. Bioresource Technology, 74, pp. 25-33, 2000.

[8] Jeong, TS., Byung, HU., Jun-Seok, K., Kyeong-Keun, O., Optimizing dilute acid pre-treatment of rapeseed straw for extraction of hemicellulose, Applied Biochemistry and Biotechnology, 161, pp. 22-33. 2010.

[9] Castro, E., Diaz, MJ., Cara, C., Ruiz, E., Romero, I., Moya M., Dilute acid pre-treatment of rapeseed straw for fermentable sugar generation, Bioresource Technology, 102, pp. 1270-1276, 2011.

[10] Mathew, A.K., Humphries, A.C., Chaney, K., Crook, M., Dilute acid pretreatment of Oilseed rape straw for bioethanol production. Renewable Energy. Article in press, .doi:10.1016/j.renene. 2011.01.030, 2011.

[11] Swain, MR., Kar, S., Sahoo, AK., Ray, RC., Ethanol fermentation of mahula (Madhuca latifolia L.) flowers using free and immobilized yeast Saccharomyces cerevisiae. Microbiology Journal Research, 162,pp. 93-98, 2007.

[12] Liu R, Li J., Shen, F., Refining bioethanol from stalk juice of sweet sorghum by immobilised yeast fermentation, Renewable Energy 33, pp.1130-1135, 2008.

[13] Bezbradica, D., Obradovic, B., Leskosek-Cukalovic, I., Bugarski, B., Nedovic, V., Immobilisation of yeast cells in PVA particles for beer production, Process Chemistry, 42(9), pp. 1348-1351, 2007.

[14] National renewable energy laboratory, http://www.nrel.gov/biomass/

[15] Kuhad, RC., Gupta, R., Khasa, YP., Singh, A., Bioethanol production from Lantana camara (red sage): pre-treatment, saccharification and fermentation, Bioresource Technology, 101, pp. 8348-8354, 2010.

[16] Christensen, CH., Jorgensen, B., Rass-Hansen, J., Egeblad, K., Madsen, R., Kiltgaard, SK., Hansen, SM., Hansen, MR., Andersen, HC., Riisager, A.. Formation of acetic acid by aqueous phase oxidation of ethanol with air in the presence of heterogeneous gold catalyst, Angewandte Chemie International Edition, 45, pp. 4648-4651, 2006.

[17] Cheng, J., Biomass to renewable energy processes, CRC press, Taylor \& Francis group, pp. 240-241, 2009.

[18] Ramon-Portugal, F., Pingaud, H., Strehaiano, P., Metabolic transition step from ethanol consumption to sugar/ethanol, Biotechnology Letters, 26, pp. 1671-1674, 2004. 
[19] Behera, S., Kar, S., Mohanty, RC., Ray, RC., Comparative study of bioethanol production from mahula (Madhuca latifolia L.) flowers by Saccharomyces Cerevisiae cells immobilised in agar-agar and Ca-alginate matrices. Applied Energy, 87, pp. 96 - 100, 2010.

[20] Rakin M, Mojovic L, Nikolic S, Vukasinovic M, Nedovic V. Bioethanol production by immobilised Saccharomyces Cerevisiae var. ellipsoideus cells. African Journal of Biotechnology, 8, pp. 464-471, 2009.

[21] Yu, J., Zhang, X., Tan, T., An novel immobilisation method of Saccharomyces cerevisiae to sorghum bagasse for ethanol production, Journal of Biotechnology, 129, pp. 415-420, 2007.

[22] Najafpour, G., Younesi, H., Ku, S., Ku, I., Ethanol fermentation in an immobilised cell reactor using Saccharomyces cerevisiae. Bioresource Technology, 92, pp. $251-260,2004$.

[23] Modig, T., Liden, G., Taherzadeh, M.J., Inhibition effects of furfural on alcohol dehydrogenase, aldehyde dehydrogenase and pyruvate dehydrogenase. Biochemical Journal, 363, pp. 769-776, 2002.

[24] Petersson, A., Thomsen, M.H., Nielsen, H.H. and Thomsen, A.B., Potential bioethanol and biogas production using lignocellulosic biomass from winter rye, oilseed rape, faba been, Biomass and Bioenergy, 3, pp. 812-819, 2007.

[25] Nedovic, V. \& Willaert R., Applications of cell immobilisation biotechnology, Springer publications, ISBN: 978-1-4020-3229-5, 2005. 